\title{
An Approach to Building ICT Capabilities in Nonprofits
}

\author{
Mehruz Kamal \\ State University of New York at Brockport \\ mkamal@brockport.edu
}

\begin{abstract}
Over the years, the Digital Divide has focused primarily on the fear that specific groups of people will be left behind in an increasingly technical world. Less, however, has been said about the probability of an organizational digital divide, e.g., that nonprofits may not have access to developing technical capability. The fundamental belief is that nonprofits are at a disadvantage when it comes to adopting and maintaining current information technology systems due to a variety of challenges that they face. The goal of this study was to investigate and assess such adoption through a very systematic and contextualized approach. An action research methodology was used to investigate a nonprofit organization in Western New York during a five-month timespan. The contribution of this study is in applying a modified adaptation of the capabilities framework to understand the nature of the grass-root level impact within the nonprofit from the technology adoption and use.
\end{abstract}

\section{Introduction}

Current research has investigated the effect of ICTs on human, social and economic development. Human development is seen to be a key determinant of successful ICT adoption in developing regions. This concept according to [29] suggests that people need to be in control of their lives in order to take the opportunities presented to them. Authors of past research suggest that human development entails access to services such as healthcare, education and governance [7], [11], [22], [26], [28]. The research on social development suggests that implementations of technology in eGovernment [5], [17], [30], [33], healthcare [3], [13], [20], [21], education [9] and the environment have had the effect of bringing about better lives for people in underserved communities. Economic development perspectives measure growth in terms of income generation, job creation, and/or reduction in poverty [35], [27], [1]. While these numbers are used in making policy decisions, they often overlook the informal sector where most of the resource constrained organizations operate. They do not represent the extent to which actual development (or the lack thereof) is taking place within the most underserved communities.

This research suggests that while human, social and economic development perspectives are important and ICT adoption has the potential to enable those outcomes to be achieved, little has been done to find the connections between these concepts [2], [6], [18], [24]. Those researchers make an effort in this direction by bringing to light the different perspectives that are being used in implementing IT for spatial data infrastructures. This paper suggests that when ICT implementations address all three issues, they increase the chances of success of those implementations, particularly with regard to resource-constrained organizations such as nonprofits.

Concern over the digital divide has focused primarily on the fear that specific groups of people will be left behind in an increasing technical world. Less, however, has been said about the probability of an organizational digital divide, for example, that nonprofit organizations may not have access to developing technical capability. The prevailing belief is that nonprofits are at a disadvantage in maintaining current computer systems. Nonprofit organizations use computers, Internet and other networking technology for a number of tasks, including volunteer management and support, donor management, client tracking and support, project management, financial accounting, program evaluation, research, marketing, activism and collaboration. Because of their limited budgets, nonprofit organizations may not be able to upgrade their hardware or software, buy computers or Internet tools, or provide technology training for staff to the degree of for-profit businesses. This means that, often, nonprofit organizations can be on the wrong side of the digital divide. Nonprofit organizations are extremely diverse in size, mission, and nature [10]. As a result, nonprofit organizations differ in their use of technology and the impact that technological changes make upon them [12].

It then appears that there is a need to apply a systematic approach to facilitating the adoption and use 
of information technology in nonprofits. The research questions therefore, being addressed in this study are, How can resource constrained nonprofits build ICT capabilities? and, What is the impact on such nonprofits from ICT adoption and use? In this study, we investigate these research questions by analyzing a single in-depth case study of a local nonprofit organization in using technology to overcome some of their challenges using a contextualized approach. An action research methodology was used to investigate a nonprofit in Western New York during a five-month timespan. The contribution of this study is in applying a modified adaptation of the capabilities framework to understanding the nature of the grass-root level impact within the nonprofit from the ICT adoption and use.

\section{Background}

\subsection{Nonprofits and Information Technology}

There is a growing literature on the potential benefits of using computer and networking technology in nonprofit organizations. Ferraro [8] emphasizes the benefits that more immediate access to information has had on service-providing nongovernmental organizations. The Internet is frequently cited as a cost effective tool for fundraising [36], [34], recruiting members and volunteers, announcing jobs, and coordinating advocacy efforts [37]. Additionally, using appropriate software can help nonprofits streamline financial management, cut costs, and offer services more effectively [23].

Although the benefits of computer technology for nonprofits seem well established, there is a fair amount of anecdotal evidence that nonprofits suffer from "the digital divide." Until very recently, nonprofits have failed to see the significance of changing technologies on service delivery [15]. For example, in 1986, one of the most frequently cited works on the future of the nonprofit sector included an extensive list of future research but failed to mention technology [31]. More recently, attention has turned to the role of computer technology in the nonprofit sector, as evidenced by the subject of a recent Independent Sector's annual symposium, "The Impact of Information Technology on Civil Society." In the last decade, a few studies have explored the degree of utilization of technology by nonprofits, but a good base of systematic research is lacking. In 1990, a small team of researchers completed a study on ten "cultural" nonprofits (those involved in the performing and visual arts) in Cleveland, Ohio. The major conclusion was that nonprofit cultural institutions engage in only a limited way with Information Systems (IS) and other computer technology. They attribute this deficiency to an overwhelming lack of strategy regarding the uses of technology and the inability of these nonprofits to contribute funding or staff to develop IS applications [32].

Other trends in the literature include the presumption that nonprofits are technologically disadvantaged and describe efforts to alleviate this problem, rather than diagnosing the problems first. Evidence of this assumption is the donation by some private organizations and online nonprofits of volunteers, services, and on-line tools to these disadvantaged nonprofits free of charge [4], [14], [25]. Others have discussed the use of more traditional techniques such as partnerships with for-profits to creatively finance computer systems [19]. Finally, some caution that perceived difficulties with technology may in fact be difficulties managing technology, a very different problem indeed. Kleintop [16] focuses on management of information technology in nonprofits, making a strong argument that good management approaches and techniques are essential to addressing any underlying problem of a lack of resources.

\subsection{ICTs, Capabilities, and Development}

This research will draw upon the field of Information Technology for Development (ITD) to understand and assess the impact of ICTs in nonprofits. The field of ITD entails the implementation, use and management of Information Technology infrastructures to stimulate human, social and economic development [42]. However, it is first important to have an understanding of what is meant by development. In order to do this, we draw on Sen's view of development - which essentially considers development to mean an increase in freedom, both the freedoms of what one can do in theory, and the freedoms of what one can actually do in practice.

Freedoms are understood as two related things capabilities and functionings. In simple terms, "a functioning is an achievement, whereas a capability is the ability to achieve" [44]. From their set of capabilities, a person has a choice about what they seek to realize as functionings; with realized functionings being "what a person is actually able to do" [44]. According to Sen's capabilities approach, development can, therefore be understood as combining three things. On a broad scale, expansion of the contextual capabilities that provide a context of opportunities. And at a narrower scale, expansion of the specific capabilities an individual can select from, and expansion of the realized functionings they are able to 
do or be in practice. These differences create the basis to understand the pattern of incremental development.

For this study, we use Sen's capability framework as a foundational lens to assess the impact of ICTs. Heeks (2018) built on work done by Zheng and
Walsham [47] to link ICTs directly to Sen's ideas. The conceptual model is shown in Figure 1 below.

\begin{tabular}{|c|c|c|c|c|}
\hline $\begin{array}{l}\text { Digital } \\
\text { commodities e.g. } \\
\text { hardware, software }\end{array}$ & $\begin{array}{l}\text { Differences \& } \\
\text { Opportunities }\end{array}$ & $\begin{array}{c}\text { Digital capabilities } \\
= \\
\text { Vectors of }\end{array}$ & Values \& Choice & $\begin{array}{l}\text { Realized digitally- } \\
\text { enabled } \\
\text { functionings }\end{array}$ \\
\hline $\begin{array}{l}\text { and their } \\
\text { functionalities e.g. } \\
\text { digital data } \\
\text { processing } \\
\text { /communication }\end{array}$ & $\begin{array}{l}\text { E.g. personal, } \\
\text { social and } \\
\text { environmental } \\
\text { conversion factors }\end{array}$ & $\begin{array}{l}\begin{array}{l}\text { functionings } \\
\text { (affordances) }\end{array} \\
\text { e.g. digital } \\
\text { communication }\end{array}$ & $\begin{array}{l}\text { E.g. personal } \\
\text { preferences, } \\
\text { needs, or social } \\
\text { pressures }\end{array}$ & $\begin{array}{l}\text { e.g. faster and easier } \\
\text { access to better } \\
\text { information }\end{array}$ \\
\hline
\end{tabular}

Figure 1. ICTs and the Capabilties Framework (Heeks 2018)

In this model, ICTs are considered to be commodities [47], [4]. ICT commodities are a means to achieve functionings such as information, communication, computation, transaction, coordination, etc. Which of these baseline functionalities of ICTs actually becomes a capability in any given context depends on a set of conversion factors. Heeks (2018) outlines the following conversion factors: (i) Personal - an individual's resource endowment, (ii) Social - the institutional and other structural conditions in a particular context, and (iii) Environmental - including geography, human/technological infrastructure, and other public goods and resources. Then, from among the digital capabilities - what an individual is able to achieve with ICTs - they will choose the particular digital functionings to achieve such as better communication, increased knowledge, etc. Choice is determined by a combination primarily of personal and social/institutional factors, though wider environmental elements may play a role. We use the Heeks [40] model to make sense of the impact of ICTs in nonprofits.

\section{Methodology}

This study uses an inductive interpretive case study [46] to understand ICT adoption and use in a nonprofit to facilitate development. An action research methodology [38] is used to apply ICT interventions within a nonprofit organization in Western New York, a region known for its high poverty levels and lack of resources, and the results analyzed.
The research design used is shown in Figure 2 below. As seen in the Figure 2, there are four distinct stages at which activities will be conducted.

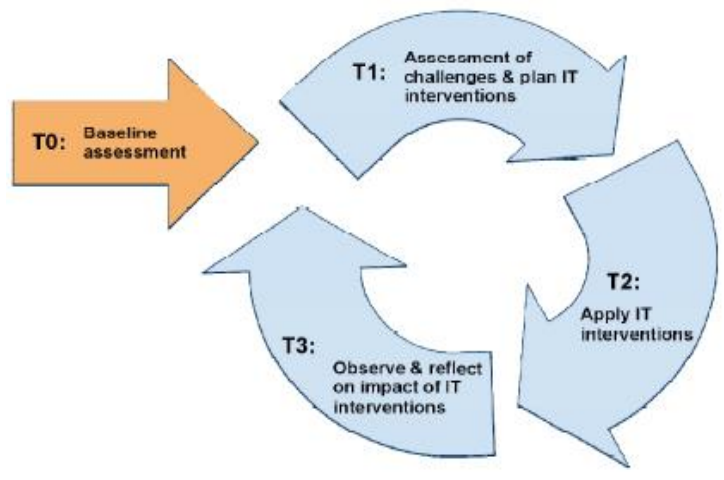

Figure 2. Research Design

At T0, the researcher will interview the President along with the board members of the nonprofit organization, to understand their past, present, and future use of technology, and how they think ICT could benefit the organization. Stages T1 through T3 comprise the action research cycle that will be conducted. At T1, the researcher will once again meet with the President to inquire about any of the immediate ICT needs and also get an in-depth understanding of the business. Equipped with that information along with the information obtained from the interviews at the T0 stage, the researcher will then plan what type of ICT intervention would be appropriate to apply to the nonprofit. At T2, the actual ICT interventions will be applied. At stage T3, the researcher will evaluate whether the ICT interventions applied to the nonprofit actually meets and/or solves 
the needs expressed by the President of the nonprofit. If not, then modifications are made and additional ICT interventions are applied.

Iteration between stages $\mathrm{T} 1$ through $\mathrm{T} 3$ represents the cyclical nature of the action research approach. The researcher will then integrate all the data from the interviews and observations and carry out an in-depth case analysis to understand the nature of the impact in the nonprofit from the ICT adoption and use within the context of socioeconomic development.

\section{The Case}

A nonprofit organization was selected for this study. A key selection criterion was the willingness to grow their organization with technology. The nonprofit foundation provides resources to support $\mathrm{K}-12$ students in the local School District. The goal of the nonprofit is to support students academically, provide classroom grants, and offer program enrichment by providing funding that typically is not available through the regular school district budgets.

The nonprofit foundation raises funds entirely through donations from individuals. Currently, there are twelve members that make up the foundation board. Most of the members are retirees that volunteer their time to serve on the board because they believe in the mission of the nonprofit organization. The entire board meets once every month to discuss and make final decisions on actions to be taken by the nonprofit organization. For the purpose of this study, the President of the nonprofit foundation was the key person that was the main point of contact.

\section{Results from the Case}

\subsection{T0 - Baseline Assessment}

The researcher met with the President of the nonprofit and asked questions regarding how he/she perceived information technology and how he/she thought their organization might benefit from technology. Table 1 gives a summary of the findings.

\section{Table 1. Baseline Assessment}

- All board members including the President does not possess IT skills

- President is open to new ideas and new technologies

- President has a willingness to learn and an openmindedness that is ideal for adopting new technologies.
- All board members realize that a major critical success factor for the nonprofit is the use of technology to get their message out and promote the purpose of their organization.

- Donations are the key to achieving their mission of helping the faculty and students of the school district. Subsequently, finding ways to use technology to drive and increase donations is extremely important.

\subsection{T1 - Assessment of Challenges \& Plan IT Interventions}

The interview responses from the $\mathrm{T} 0$ stage provide an initial glimpse as to how the board members of the nonprofit view technology. Once the initial assessment is completed, the researchers then interviewed the President again - with open-ended questions - but this time with the intention to get a better in-depth understanding of the historical and social context of the business (Table 2 below). Doing so enabled the researcher to decide on appropriate ICT interventions to apply.

\section{Table 2. Assessment of Challenges}

- Currently, funding requests are made via paper applications, which are either mailed in or faxed in.

- No website/social media presence exists to promote the nonprofit's mission thereby limiting exposure/awareness to prospective donors

- President \& board members have limited to no technical skills in developing website and integrating social media

- No means to donate online (currently donations made via checks that are mailed in).

- All funding applications and approvals are stored in paper form with no back-ups.

- Outdated hardware (current computer has low RAM \& very slow).

\subsection{T2 - Apply IT Interventions}

Based on responses from the $\mathrm{T} 0$ and $\mathrm{T} 1$ phases, the following interventions were carried out for the nonprofit organization. 
Table 3. IT Interventions

- Created a professional \& user-friendly website to promote organization that is easy to update using a content management system - Squarespace.

- Created an electronic version of grant application form and enabled submission of it via new website.

- Created and integrated social media accounts on Facebook and Twitter with new website

- Enabled online payment of donations through PayPal via new website. Established nonprofit status for PayPal account to obtain better rate.

- Set up Google drive to store \& organize paperwork for easy access. Integrated online grant application to save to Google drive.

- Trained President on how to maintain website, social media account, \& Google drive.

\subsection{T3 - Observation \& Reflection}

Over the course of five months during which the ICT adoption was being carried out, the President of the nonprofit organization continued to show a positive attitude towards incorporating technology into their operations. All board members of the nonprofit foundation understood the importance of technology and that it could help promote and farther the mission of the organization. Additionally, since the entire board only meets once a month, they all agree that technology is very important for the organization to run and to best use the time that they are able to meet to discuss important issues instead of taking care of administrative tasks. They also realize that being more involved with technology related applications such as social media and their own website will help publicize their organization's goal and will help advertise their fundraising events to the local and non-local communities.

The President along with the rest of the board members are older citizens possessing little to no ICT skills. However, this skill barrier was overcome by providing very context-sensitive training and by providing all board members with very detailed user guides on how to operate the Google Drive and customize/add/edit their new website and social media account. There was no noticeable resistance towards the adoption of the various technology applications introduced. The President was very willing to learn what she needed to in order to be able to maintain the website for the organization.

When potential donors are presented with well-kept and well-managed website/social media sites, they will be more likely to donate. These technologies add a degree of prestige to the organization and make it more desirable for people to donate and get involved. This will also increase the organization's competitiveness against other closely related nonprofit organizations.

\section{Understanding Socio-economic Impact through the Capabilities Framework}

Our analysis of the case is summarized in table 4. The interventions carried out, and outcomes obtained from the case are correlated to Heek's (2018) adapted capabilities conceptual model (figure 1).

Humans are diverse and have different opportunities to benefit from interventions. This is essential in our analysis of ITD interventions. "We are deeply diverse in our internal characteristics (such as age, gender, general abilities, particular talents, proneness to illness, and so on) as well as in external circumstances (such as ownership of assets, social backgrounds, environmental predicaments, and so on)" [45]. In our analysis, we have to take this into consideration and look at what conversion factors (personal, social and environmental) prevent individuals from expanding their capabilities. In ITD projects we can either, design the intervention to fit within the context or design interventions that change the context (i.e. the intervention can remedy problematic conversion factors) [39].

It then appears that the phases we carried out and described in the methodology section above i.e. T0 T3 serve as an integrated conversion factor. These phases together provided the requisite information as to the challenges faced within the nonprofit context. The challenges identified, lead systematically to applying the right intervention to ameliorate the situation. For example, one of the digital commodities was an online content management system. Phase, T1 revealed the reasons behind the need for the digital commodity. Phase T2 enabled the digital commodity to transform into a digital capability through the outcome of a new redesigned customized website for the nonprofit organization.

Conversion factors will influence both the enablement of potential functioning and the ability of people to utilize the potential functioning i.e. their ability to make choices. What functionings the intervention enables must be evaluated within the context where it is deployed [39]. Accordingly, in order to achieve greater realization of the digital functionings, our methodology of cycling through T1 T3 (figure 2) and context-based technology training as outlined in table 3 helped to build personal confidence in the President's technology skills. Subsequently, this allowed the President to choose the digital capabilities 
that will provide the greatest value for the nonprofit organization as outlined in the last column in table 4. This idea integrated with the data outlined in table 4 is represented by figure 3 following table 4 below.

Table 4. Impact on Socio-economic Development

\begin{tabular}{|c|c|c|}
\hline $\begin{array}{l}\text { Means to achieve } \\
\text { Digital commodities }\end{array}$ & $\begin{array}{l}\text { Freedom to achieve } \\
\text { Digital capabilities }\end{array}$ & $\begin{array}{c}\text { Achievement } \\
\text { Realized digitally-enabled Functionings }\end{array}$ \\
\hline $\begin{array}{l}\text { Online Content } \\
\text { Management System } \\
\text { (Squarespace) }\end{array}$ & $\begin{array}{l}\text { Customizable } \\
\text { website }\end{array}$ & $\begin{array}{l}\text { - } \quad \text { Generating awareness to the foundation } \\
\text { - } \quad \text { Feaching out to potential donors } \\
\text { showcasing credibility \& accountability by } \\
\text { online photos of activities from grants awarded. } \\
\text { - Drive donations }\end{array}$ \\
\hline Online social media & $\begin{array}{l}\text { Online marketing } \\
\text { Engaging donors \& } \\
\text { volunteers online }\end{array}$ & $\begin{array}{l}\text { - The President is now able to use social media to } \\
\text { promote the organization's mission } \\
\text { - Can interact with donors through online posts } \\
\text { - Can promote fundraising events to drive donations } \\
\text { - Facilitate Volunteer engagement }\end{array}$ \\
\hline $\begin{array}{l}\text { Online Grant } \\
\text { application }\end{array}$ & $\begin{array}{l}\text { Electronic grant } \\
\text { application } \\
\text { submission }\end{array}$ & $\begin{array}{l}\text { - Grant application can now be made electronically } \\
\text { - } \quad \text { Saves time in application processing } \\
\text { - } \quad \text { Can be easily shared with all board members }\end{array}$ \\
\hline $\begin{array}{l}\text { Online Donation } \\
\text { payment (PayPal) }\end{array}$ & $\begin{array}{l}\text { One-click donation } \\
\text { payments }\end{array}$ & $\begin{array}{l}\text { - } \quad \text { Efficiently accept donor payments } \\
\text { - Saves time processing donations } \\
\text { - Can now easily reach donors \& accept donations } \\
\text { outside of local geographic area. } \\
\text { - Can facilitate greater number of donations }\end{array}$ \\
\hline $\begin{array}{l}\text { Online Document } \\
\text { storage (Google } \\
\text { Drive) }\end{array}$ & $\begin{array}{l}\text { Document storage, } \\
\text { organization \& } \\
\text { backup }\end{array}$ & $\begin{array}{l}\text { - All grant applications \& approvals stored \& backed } \\
\text { up electronically } \\
\text { - Cost savings from reduction in paper usage } \\
\text { - One common shared repository of information } \\
\text { - } \quad \text { Easily accessible by all board members }\end{array}$ \\
\hline
\end{tabular}




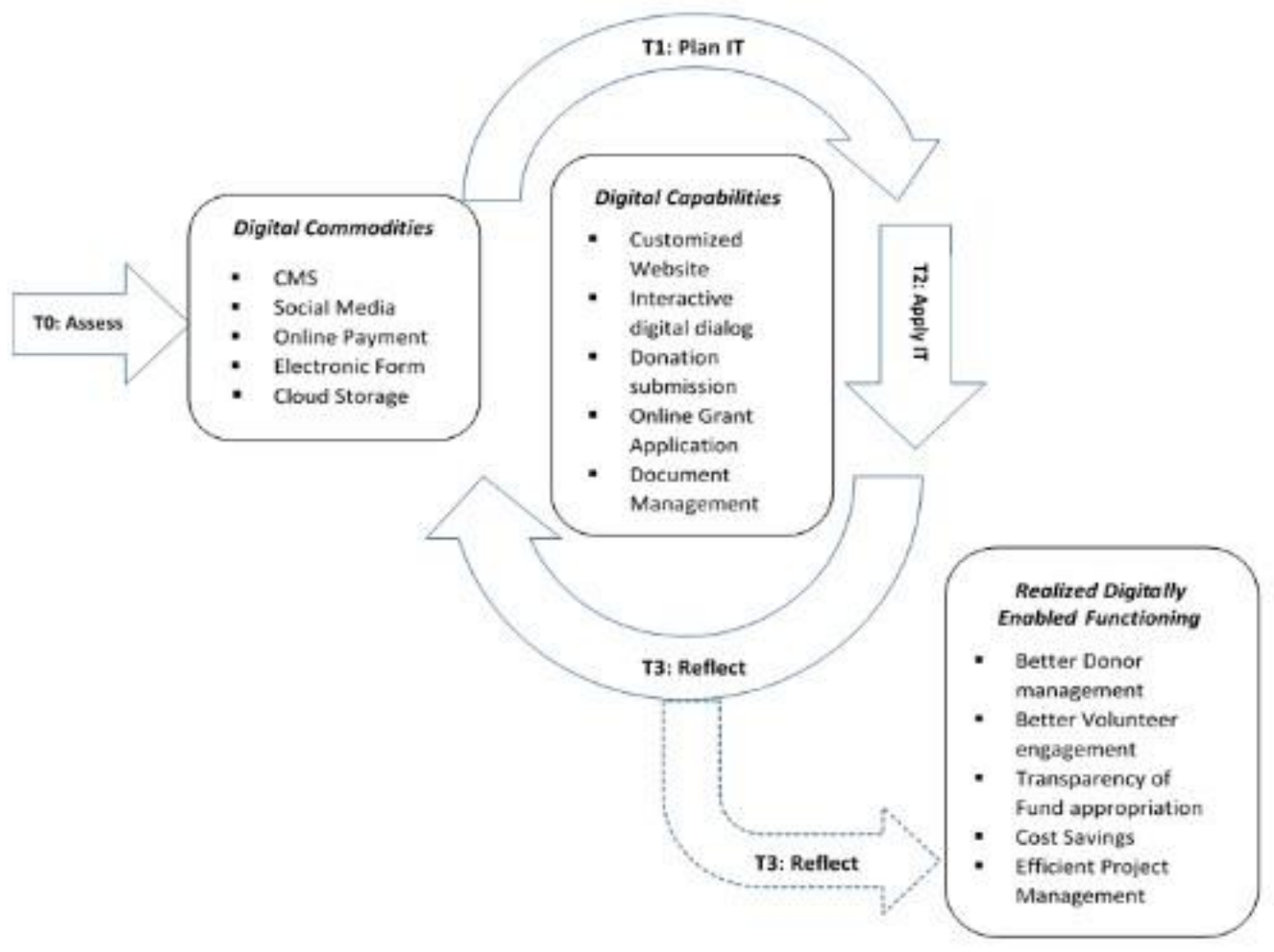

Figure 3. An approach to building ICT capabilities in Nonprofits

The analysis presented in this in-depth case study can then help us outline a number of implications that can shed preliminary light on using the capabilities framework as a lens to understanding technology adoption and use for socio-economic development at the grass-root level within the context of resourceconstrained nonprofits.

1. The capabilities framework moves us beyond jus $\mathrm{t}$ focusing on rolling out ICT infrastructure - which is just a means to achieve - and beyond just the ability to access and use ICTs - which is a freedom to achieve to think what is actually achieved by using ICTs i.e. the decisions and actions and results of those actions.

2. The framework also recognizes the enablers and barriers - skills and money; cultural norms and one's position in society; extent of infrastructure - that intervene between the technology and its effective use; and also, the personal choices people make about how to use ICTs thus linking in to ideas about motivation.

3. The capabilities perspective demands a particular approach to ITD design. Socio-economic development is no longer generic but should be brought down to the level of the individual. Discovering this requires a "radically participatory, bottom-up approach" to ITD design and implementation [41]. One that involves all beneficiaries; one that starts by discussing goals and values rather than jumping to focus on the technology; and one that retains involvement of beneficiaries throughout. This idea was operationalized in our study through the steps, $\mathrm{T} 0$ - T3 (figure 2).

4. A capabilities perspective on ICT also gives a rather different view of impact and evaluation. Instead of asking "What is the impact of ICTs?" in some general sense, a capabilities-oriented evaluation would ask, "To what extent do ICTs help people achieve the things they value doing or being?" "ICT usage patterns represent the choices people make about what is important to them and how they use technology to meet those needs" [43]. From a Senian viewpoint, then, these are developmental; they represent ICTs increasing freedoms: both substantive freedoms as ends in themselves, and also, instrumental freedoms in helping develop competencies which are means applicable to other developmental uses. 


\section{Conclusion}

The ability of resource-constrained nonprofits to adopt technology depends upon the unique conditions in which they find themselves. In this study, we investigated and assessed such adoption through a very systematic and contextualized approach. An action research methodology was used to investigate a nonprofit organization in Western New York during a five-month timespan. The contribution of this study was in applying a modified adaptation of the capabilities framework to understanding the nature of the grass-root level impact within the nonprofit from the ICT adoption and use. Using the action research methodology coupled with the capabilities perspective enabled us to take a bottom-up approach.

Which capabilities may be enabled to enrich people's lives have to come from the users themselves. This means that the analysis has to be individualistic as there will be variations within otherwise heterogeneous groups (both in terms of which capabilities they value and what factors that hinders their choices). In our study, this appropriates to the level of the President and board members of the organization. The achieved functionings were based on their context, their choice, and their ability to use the technology applications, as they deemed appropriate. Using a bottom-up contextualized approach, we captured the functionings that the technology interventions actually enabled, and not just how the outcome maps against the implemented intervention.

This study provides insights for both academia and practice. For academia, the integration of the action research steps outlined along with the capabilities framework perspective presents a better lens for socioeconomic development analysis at the individual level. It is better in the sense that the focus is on ends and not means, the case study is viewed within the context where it is deployed and we gain a better understanding of why and how socio-economic development come about. For the practitioner community, insights from this study can be used when planning and initiating ITD projects. The action research-capabilities perspective will focus practitioners' attention to all aspects of the intervention, including the context (conversion factors) and the notion of choice.

Future studies will entail a longitudinal monitoring of ICT use and its subsequent socioeconomic impact within the nonprofit organization. In addition, the framework presented in this study will be applied to study similar resource constrained nonprofits and carry out in-depth cross-case analysis to generalize the findings.

\section{References}

[1] Abraham, R. "Mobile Phones and Economic Development: Evidence from the Fishing Industry in India". Information and Technologies and International Development, Vol. 4, No. 1, 2007.

[2] CÃ $₫$ mara, G., Fonseca, F., Monteiro, A.M., and Onsrud, H. "Networks of innovation and the establishment of a spatial data infrastructure in Brazil," Information Technology for Development (12:4) 2006, pp 255-272.

[3] Chilundo, B., and Sahay, S. "HIV/AIDS reporting systems in Mozambique: The theoretical and empirical challenges of representations." Information Technology for Development (11:3) 2005, pp 245-272.

[4]Corrigan, S. Technology Donations. Communications of the ACM 36: 13-14. 1993

[5] Ciborra, C., and Navarra, D.D. "Good governance, development theory, and aid policy: Risks and challenges of e-government in Jordan," Information Technology for Development (11:2) 2005, pp 141-159.

[6] Davis Jr, C.A., and Fonseca, F. "Considerations from the development of a local spatial data infrastructure," Information Technology for Development (12:4) 2006, pp 273-290

[7] Ezer, J. "Gandhi's third assassination: Information and communications technology education in India," Information Technology for Development (12:3) 2006, pp 201-212.

[8] Ferraro, P. Legal and Organizational Practices in Nonprofit Management. Boston: Kluwer Law International. 2000 .

[9] Furuholt, B.r., and Ã rvik, T.U. "Implementation of information technology in Africa: Understanding and explaining the results of ten years of implementation effort in a Tanzanian organization," Information Technology for Development (12:1) 2006, pp 45-62.

[10] Hodgkinson, V. A. Key Challenges Facing the Nonprofit Sector. In V.A. Hodgkinson, R.W. Lyman \& Associates (Ed.), The Future of the Nonprofit Sector: Challenges, Changes, and Policy Considerations. San Francisco: Jossey-Bass. 1989.

[11] Jacucci, E., Shaw, V., and Braa, J.r. "Standardization of health information systems in South Africa: The challenge of local sustainability," Information Technology for Development (12:3) 2006, pp 225-239.

[12] Kearns, K. P. Private Sector Strategies for Social Sector Success: The Guide to Strategy and Planning for Public and Nonprofit Organizations. San Francisco: Jossey-Bass. 2000. 
[13] Kimaro, H.C., and Nhampossa, J.L. "Analyzing the problem of unsustainable health information systems in less developed economies: Case studies from Tanzania and Mozambique." Information Technology for Development (11:3) 2005, pp 273-298.

[14] King, J. IS Volunteers Get on Board Web TRAIN. Computerworld 3: 12. 1997.

[15] Kirk, W. A. Nonprofit Organization Governance: A Challenge in Turbulent Times. New York: Carlton Press. 1986.

[16] Kleintop, W. A. Information Resource Management for Nonprofit Organizations. In T.D. Connors (2d Ed.), The Nonprofit Handbook: Management. New York: John Wiley \& Sons. 1997.

[17] Krishna, S., and Walsham, G. "Implementing public information systems in developing countries: Learning from a success story," Information Technology for Development (11:2) 2005, pp 123-140.

[18] Lance, K., and BassolÃ@), A. "SDI and national information and communication infrastructure (NICI) integration in Africa," Information Technology for Development (12:4) 2006, pp 333-338.

[19] Leibowitz, W. R. Not-For-Profit Legal Organizations are Wiring Up on Small Budgets. The National Law Journal 19: C30. 1998.

[20] LuÃs Mosse, E., and Byrne, E. "The role of identity in health information systems development: A case analysis from Mozambique." Information Technology for Development (11:3) 2005, pp 227-243.

[21] Mosse, E.L., and Sahay, S. "The role of communication practices in the strengthening of counter networks: Case experiences from the health care sector of Mozambique," Information Technology for Development (11:3) 2005, pp 207-225.

[22] Musa, P.F. "Making a case for modifying the technology acceptance model to account for limited accessibility in developing countries." Information Technology for Development (12:3) 2006, pp 213-224.

[23] Ouellette, T. Nonprofits Rely on IS Innovation. Computerworld 16: 6. 1996.

[24] Puri, S.K. "Technological frames of stakeholders shaping the SDI implementation: A case study from India," Information Technology for Development (12:4) 2006, pp 311-331.

[25] Raths, D. IT Pros Lend a Hand to Close Digital Divide. Information Week 22: 97. 2000.

[26] Reinhard, N., and Macadar, M.A. "Governance and management in the SÃ£o Paulo Public Telecenter Network.,"
Information Technology for Development (12:3) 2006, pp 241-246.

[27] Röller, L., and Waverman, L. "Telecommunications Infrastructure and Economic Development: A Simultaneous Approach," The American Economic Review (91:4) 2001, pp 909-923.

[28] Sahay, S., and Walsham, G. "Scaling of health information systems in India: Challenges and approaches.," Information Technology for Development (12:3) 2006, pp $185-200$

[29] Sen, A. Development as Freedom Oxford University Press, Oxford, 1999, p. 366.

[30] Shaomin, L. "The impact of information and communication technology on relation-based governance systems," Information Technology for Development (11:2) 2005, pp 105-122.

[31] Simon, J. G. Agendas for Nonprofit Sector Research. In A. Hodgkinson, R. W. Lyman, \& Associates (Ed.), The Future of the Nonprofit Sector: Challenges, Changes, and Policy Considerations. San Francisco: Jossey-Bass. 1989.

[32] Te'eni, D. \& Speltz N. F. Management Information Systems in Cultural Institutions. In D.R. Young, R.M.

Hollister, V.A. Hodgkinson, \& Associates (Ed.), Governing, Leading, and Managing Nonprofit (pp.77-92). San Francisco: Jossey-Bass. 1993.

[33] Ulrich, P., and Chacko, J.G. "Overview of ICT policies and e-strategies: An assessment on the role of governments," Information Technology for Development (11:2) 2005, pp 195-197

[34] Vimuktanon, A. Non-Profits and the Internet. Fund Raising Management 28: 25-29. 1997.

[35] Waverman, L., Meschi, M., and Fuss, M. "The impact of telecoms on economic growth in developing countries," The Vodafone Policy Paper, Series 2, 2005.

[36] Wong, W. Nonprofits Find Funds, Help on the Web. Computerworld 22: 37-38. 1997.

[37] Zeff, R. Navigating the Internet for Nonprofits. In T.D. Connors (2d Ed., Ed.), The Nonprofit Handbook: Management. New York: John Wiley \& Sons. 1997.

[38] Baskerville, R.L. "Investigating Information Systems with Action Research." Communications of the Association for Information Systems, 2. 1999.

[39] Hatakka, M. and De, R. "Development, capabilities and technology: an evaluative framework." Proceedings of the 11th International Conference on Social Implications of Computers in Developing Countries, Kathmandu, Nepal. 2011 
[40] Heeks, R. "Information and Communication Technology for Development.” Routledge. 2018.

[41] Kleine, D.,Light, A. and Montero, M. J. "Signifiers of the life we value?" Information Technology for Development, 18, 1, 42-60. 2012

[42] Qureshi, S. "How does Information technology effect Development? Integrating Theory and Practice into a Process Model," Proceedings of the eleventh Americas Conference on Information Systems, Omaha, NE. 2005.

[43] Rangaswamy, N. and Cutrell, E. Anthropology, development, and ICTs. Information Technologies \& International Development, 9, 2, 51-63. 2012
[44] Sen, A. "The Standard of Living," Cambridge University Press, Cambridge, UK. 1987.

[45] Sen, A. "Inequality reexamined." Oxford: Oxford University Press. 1992.

[46] Walsham, G. "Interpretive case studies in IS research: Nature and method," European Journal of Information Systems 4, 2, 64-81. 1995.

[47] Zheng, Y. and Walsham, G. "Inequality of what? Social exclusion in the e-society as capability deprivation." Information Technology \& People, 21, 3, 222-243. 2008. 